\title{
KINETICS OF INTERACTION BETWEEN POLYREACTIVE IMMUNOGLOBULINS AND ANTIGEN
}

\author{
S. A. BOBROVNIK ${ }^{1 凶}$, O. V. OGLOBLYA2, \\ M. O. DEMCHENKO ${ }^{1}$, S. V. KOMISARENKO \\ ${ }^{1}$ Palladin Institute of Biochemistry, National Academy of Sciences of Ukraine, Kyiv; \\ ${ }^{2}$ ESC "Institute of Biology and Medicine", \\ Taras Shevchenko National University of Kyiv, Ukraine; \\ ৫e-mail: s-bobrov@ukr.net
}

Received: 28 January 2020; Accepted: 25 June 2020

\begin{abstract}
A number of experimental kinetics curves of mice polyreactive immunoglobulins (PRIGs) binding to ovalbumin immobilized on immunologic plates were obtained at different temperatures. Analysis of these curves allowed us to conclude that the model of PRIGs interaction with antigens proposed by us earlier and consisted on PRIGs activation (i.e. exposition of hydrophobic patches on PRIGs surface) and either sequential binding to antigen or inactivation was in a good agreement with the experimental data obtained in this study. We designed a method of the rate constants evaluation from experimental binding curves. It was found that the rate constant of the activated PRIGs binding to immobilized antigen did not depend on temperature. The rate constant of PRIGs activation occurred to be depend on temperature more strongly than the rate constant of PRIGs inactivation. We have concluded from the acquired dependences that at $37^{\circ} \mathrm{C}$ the number of activated PRIGs was 15 times higher than that at $0^{\circ} \mathrm{C}$.
\end{abstract}

Ke y wo rd s: polyreactive immunoglobulins, antigens, kinetics of interaction, rate constants.

A ccording to the definition, antibodies are the immunoglobulin molecules that are specific mainly to the certain antigen, against what, as a rule, these antibodies are produced. Therefore, it is obvious that quite unspecific immunoglobulin molecules able to bind in an equal degree a variety of antigens should be distinguished in the separate class of molecules. Earlier we named these molecules as polyreactive immunoglobulins (PRIGs) [2], which points on their nature, and also on their completely unspecific binding with antigens. Nevertheless, most researchers until present name them as polyreactive antibodies [3-10]. Meantime, the interest to those important molecules increases greatly.

Recent studies of PRIGs properties point to the variety of their functions and participation in quite different biological processes [3-12]. It alludes to their important role in the organism, although their basic functions and role in development of different pathologies until now remain insufficiently studied and understood. Besides, many molecular properties of PRIGs and the mode of their interaction with different antigens still now remain badly studied and require further investigations.

In this study we aimed to investigate the dependence of the dynamics of PRIGs binding with the antigen immobilized on immunological plates on the temperature of incubation and the rate constants of the different stages of this process. The obtained data indirectly confirm the binding mechanism of PRIGs with antigens suggested by us earlier and allows us to determine the ratio between concentrations of "active" and "inactive" parts of PRIGs depending on temperatures.

\section{Materials and Methods}

In this study we used PRIGs that were obtained by transformation of control (not immune) BALB/c mice serum by incubation of this serum with $3.5 \mathrm{M}$

(C) 2020 Bobrovnik S. A. et al. This is an open-access article distributed under the terms of the Creative Commons Attribution License, which permits unrestricted use, distribution, and reproduction in any medium, provided the original author and source are credited. 
$\mathrm{KSCN}$ during $5 \mathrm{~min}$ at $25^{\circ} \mathrm{C}$ and subsequent dilution of this mixture in 1000-5000 times with physiological buffered solution (PBS, $\mathrm{pH}$ 7.2). As we have shown before [2], such treatment of serum immunoglobulins results in transformation of the majority of them into PRIGs that are able to bind with various antigens nonspecifically. Obtained by such a way, PRIGs were used for study their dynamics of binding to antigens (ovalbumin, Sigma, USA) immobilized on polystyrene plates.

For immobilization of ovalbumin on polystyrene plates we used the method developed by us before, which increase the hydrophobicity of proteins that were adsorbed on polystyrene surface [13]. Briefly, ovalbumin solution $(0.1 \mathrm{mg} / \mathrm{ml})$ in $1 \%$ $\left(\mathrm{NH}_{4}\right)_{2} \mathrm{CO}_{3}$ with added $0.01 \% \mathrm{NaN}_{3}$ was placed in the wells of polystyrene plates and then dried out in a thermostat at $37^{\circ} \mathrm{C}$. Plates were carefully washed by tap water with subsequent PBS washing to remove slightly associated ovalbumin molecules immediately before experiment, and were used for the study of PRIGs binding. As we have shown before [13], such method of protein immobilization allows us to get the layer of the partially denatured molecules associated with polystyrene. Such immobilized protein molecules exhibit hydrophobic areas on their surfaces, allowing to study nonspecific PRIGs binding.

The amount of bound PRIGs with immobilized ovalbumin was determined by ELISA and has been described before [14]. For this purpose, plates with bound PRIGs were incubated with horseradish peroxidase-conjugated goat anti-mouse IgG antibodies (Sigma, USA) during $60 \mathrm{~min}$ at $4^{\circ} \mathrm{C}$. Then, after careful washing from unbound conjugates, the substrate for peroxidase, namely, the solution of $o$ phenylenediamine $(1 \mathrm{mg} / \mathrm{ml})$ in $0.01 \mathrm{M}$ phosphate buffer ( $\mathrm{pH} \mathrm{5.0)}$ and $0.003 \% \mathrm{H}_{2} \mathrm{O}_{2}$ solution was added to plates. The reaction was stopped after color developing by adding $0.05 \mathrm{ml} 2 \mathrm{M}$ sulfuric acid per wells, and optical density of solutions was measured by microphotocolorimeter ELx800, BIO-TEK, at wave length $490 \mathrm{~nm}$.

In order to use the units of absorption instead of the real PRIGs concentrations we carried out preliminary experiments to determine the initial PRIGs dilutions which allow us to obtain 2-fold, 4-fold, 8-fold etc. decrease of absorption with 2-fold, 4-fold, 8-fold etc. increase of dilution, respectively. According to our pilot experiments, PRIGs concentrations in our binding experiments performed at $0^{\circ} \mathrm{C}$ should exceed those at $37^{\circ} \mathrm{C}$ by 30 times.
In order to allow reaching the state of equilibrium between an amount of "active" and "inactive" PRIGs in the studied PRIGs solutions we prepared appropriate solutions at $4{ }^{\circ} \mathrm{C}$ and incubated them during $18 \mathrm{~h}$ before the experiment, then PRIGs solutions were incubated at the appropriate temperature no less than $2 \mathrm{~h}$. After that, the samples of PRIGs were placed in the wells of plates with adsorbed antigen in different time intervals in a manner to finalize the different incubation periods simultaneously. After finishing the incubation with PRIGs in plates, the solutions with unbound PRIGs were removed from the wells by the plates shaking and subsequent washing. Finally, plates were treated, as described above, by peroxidase-conjugated anti-Ig serum, and the amount of PRIGs bound to ovalbumin was determined by ELISA.

The acquired by this way curves of PRIGs binding at different temperatures were used for determination of the rate constants of this process by the method described below. The program was written for the computational system Mathematic (Wolfram Research) that searches for nonlinear approximation of experimental data using as an approximating function the exact solution of the differential equations suggested before for description of kinetics of the investigated process. Our program builds an interpolation function for experimental points, finds its first and second derivatives at the time zero, and by using an explicit formula for temporal dependence, finds seeding values for the kinetic parameters of model, and further searches for precise parameters by nonlinear approximation.

\section{Results and Discussion}

Fig. 1,A presents the results of PRIGs titration at $37^{\circ} \mathrm{C}$ when the time of PRIGs incubation in the plate wells with immobilized ovalbumin was 160 min. As it can be seen from Fig. 1, $A$, dilution of PRIGs samples in 2, 4, etc. times results in corresponding reduction of optical density obtained by ELISA, that allows us to use these values of absorption (i.e. optical density) for the calculations of rate constants instead of unknown for us molar concentrations of PRIGs. The result of determining the total amount of PRIGs in the samples is shown in Fig. $1, B$. In this case the PRIGs solutions were adsorbed during 6 hours to the immobilized antigen and we supposed that in this case almost all PRIGs were bound to antigen. From the data of Fig. 1,B we can conclude that the total amount of PRIGs in 
studied solutions proportional to the 20 optical units. This estimation allowed us using the data of optical density obtained by ELISA for calculation the rate constants for the reaction of PRIGs binding to the immobilized ovalbumin.

Fig. 2 represents the curves of PRIGs binding to the immobilized antigen at different temperatures. This study was carried out using different dilutions of PRIGs samples, taking into account that PRIG's binding to antigen at $27-37^{\circ} \mathrm{C}$ is much more efficient as compared to that at $0-10^{\circ} \mathrm{C}$. For that reason, PRIG's concentration in the case of binding dynamics measuring at $37^{\circ} \mathrm{C}$ was in $10-20$ times less than that at $0^{\circ} \mathrm{C}$. In order to take into account this fact, when we plotted the time-dependent plots of PRIGs binding, the values of optical density acquired by ELISA were multiplied by the corresponding number.

From the curves of Fig. 2 it is evident that a process of PRIGs binding to immobilized antigen has an extraordinarily strong dependence on the temperature. However, it is rather difficult to get any additional information about this reaction directly from these plots. Thus, it would be reasonable to study this process in detail including evaluation of rate constants and thermodynamics characteristics of the process.

As we have shown earlier, the initially "inactive" molecules of PRIGs can transform into "active" ones that are able either bind to an antigen or return to an "inactive" state. In this case the scheme of this reaction will be the following:

$$
\mathrm{N} \underset{\mathrm{k}_{2}}{\stackrel{\mathrm{k}_{1}}{\rightleftarrows}} \mathrm{A} \stackrel{\mathrm{k}_{3}}{\longrightarrow} \mathrm{C},
$$

where $N$ - concentration of "inactive" PRIGs in the solution; $A$-concentration of "active" PRIGs in the solution; $C$ - concentration of PRIGs bond to immobilized antigen; $k_{1}$ - rate constant of the transformation of "inactive" PRIGs into "active" PRIGs; $k_{2}-$ rate constant of the transformation of "active"PRIGs into "inactive" PRIGs; $k_{3}$ - rate constant of the binding of "active" PRIGs to immobilized antigen.
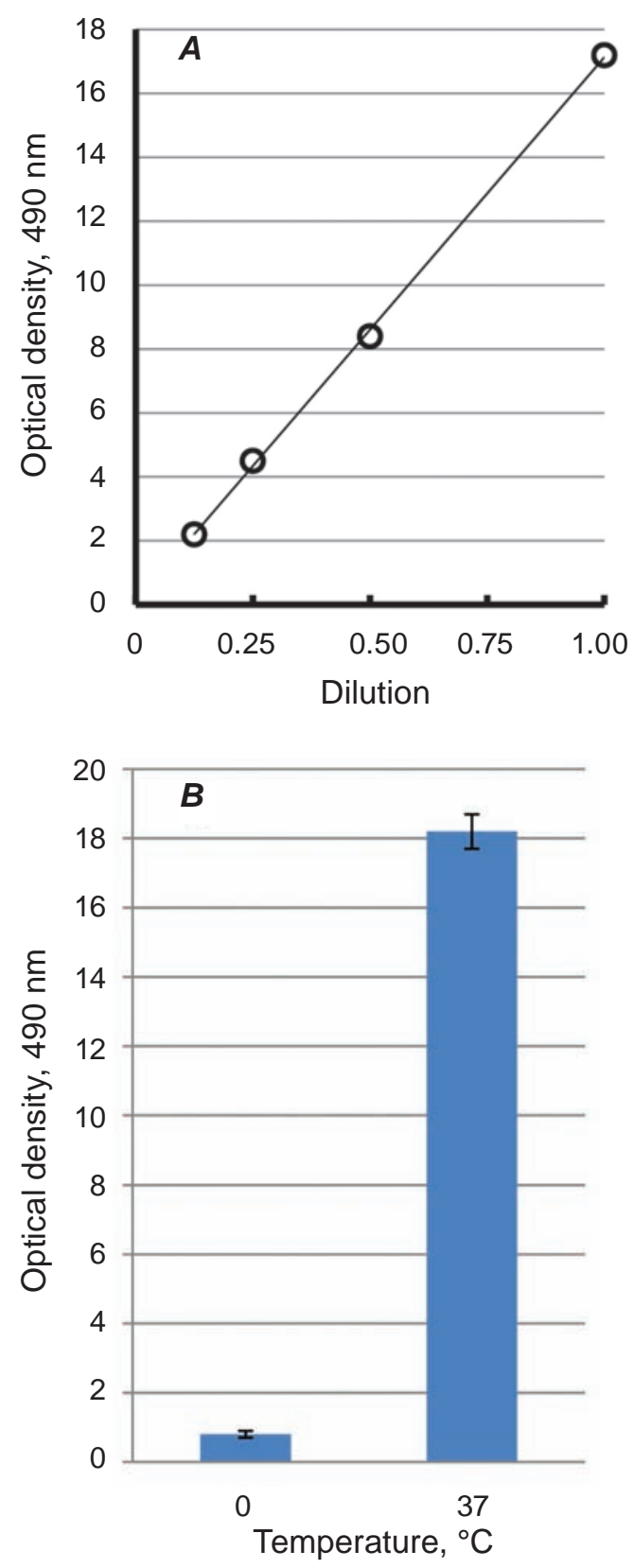

Fig. 1. A - linear dependence of optical density of wells acquired by ELISA at titration of the PRIGs samples at $37^{\circ} \mathrm{C}$ and incubation time $160 \mathrm{~min} ; \boldsymbol{B}$ dependence of amount of PRIGs bound to immobilized ovalbumin at $0^{\circ} \mathrm{C}$ and $37^{\circ} \mathrm{C}$ when the incubation time was $6 \mathrm{~h}$ 


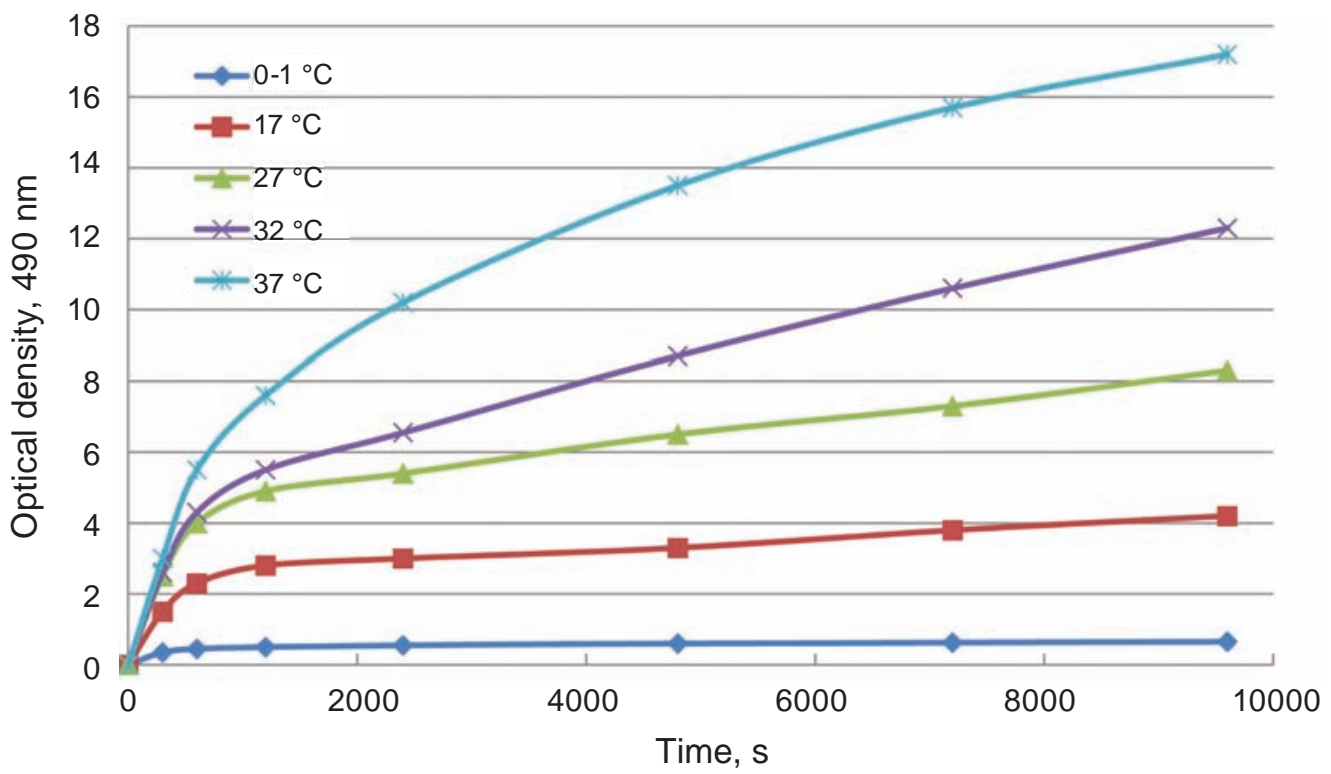

Fig. 2. Dynamics of PRIGs binding to the immobilized ovalbumin at different temperatures

If it is so, then the dynamics of the process will be described by the following system of differential equations (2):

$$
\left\{\begin{array}{c}
\frac{d N}{d t}=k_{2} A-k_{1} N \\
\frac{d A}{d t}=k_{1} N-\left(k_{2}+k_{3}\right) A(2) \\
\frac{d C}{d t}=k_{3} A
\end{array}\right.
$$

Solution of this system of differential equations (2) allows getting equation (3) that describes the dynamics of PRIGs bound to immobilized antigen, i.e. the value of $C[1]$ :

$$
\begin{aligned}
& C=S-\frac{S\left(r_{2}+k_{3}\right)\left(r_{1}+k_{2}+k_{3}\right)}{\left(k_{1}+k_{2}\right)\left(r_{2}-r_{1}\right)} e^{r_{1} t}- \\
& -\frac{S\left[k_{2}\left(r_{2}-r_{1}\right)-\left(r_{2}+k_{3}\right)\left(r_{1}+k_{2}+k_{3}\right)\right]}{\left(k_{1}+k_{2}\right)\left(r_{2}-r_{1}\right)} e^{r_{2} t}- \\
& -\frac{k_{1} S\left(r_{2}+k_{3}\right)}{\left(k_{1}+k_{2}\right)\left(r_{2}-r_{1}\right)} e^{r_{1} t}- \\
& -\frac{k_{1} S\left[k_{2}\left(r_{2}-r_{1}\right)-\left(r_{2}+k_{3}\right)\left(r_{1}+k_{2}+k_{3}\right)\right]}{\left(k_{1}+k_{2}\right)\left(r_{2}-r_{1}\right)\left(r_{2}+k_{2}+k_{3}\right)} e^{r_{2} t,}
\end{aligned}
$$

where $r_{1}=\frac{-\left(k_{1}+k_{2}+k_{3}\right)+\sqrt{\left(k_{1}+k_{2}+k_{3}\right)^{2}-4 k_{1} k_{3}}}{2}$;

$r_{2}=\frac{-\left(k_{1}+k_{2}+k_{3}\right)-\sqrt{\left(k_{1}+k_{2}+k_{3}\right)^{2}-4 k_{1} k_{3}}}{2} ; S-$ total amount of PRIGs in the study solution, i.e. $S=N+A+C$.

However, it is necessary to take into account that the scheme of the reactions (1) is not exact be- cause it does not take into account a possibility of unspecific binding of two active molecules of PRIGs with each other. Taking this fact into account will result in considerable complication of scheme (1) and corresponding system of differential equations would not allow obtaining an analytical solution. However, we assumed that due to very small concentration of PRIGs in our experiments, a concentration of PRIGs molecules bound to each other will be close to zero, and because of this it is possible to ignore it.

Nevertheless, it would be desirable to get the experimental proofs that the binding scheme (1) and equation (3) describe examined process with sufficient precision. In order to do that, the following transformation of equation (3) can be performed. We can move $S$ value from the right side of equation (3) to the left part, and then to divide both parts of equation by $S$. After this we can get the following dependence:

$$
\begin{aligned}
& \frac{S-C}{S}=\frac{\left(r_{2}+k_{3}\right)\left(r_{1}+k_{2}+k_{3}\right)}{\left(k_{1}+k_{2}\right)\left(r_{2}-r_{1}\right)} e^{r_{1} t}+ \\
& +\frac{k_{1}\left(r_{2}+k_{3}\right)}{\left(k_{1}+k_{2}\right)\left(r_{2}-r_{1}\right)} e^{r_{1} t}+ \\
& +\frac{\left[k_{2}\left(r_{2}-r_{1}\right)-\left(r_{2}+k_{3}\right)\left(r_{1}+k_{2}+k_{3}\right)\right]}{\left(k_{1}+k_{2}\right)\left(r_{2}-r_{1}\right)} e^{r_{2} t}+ \\
& +\frac{k_{1}\left[k_{2}\left(r_{2}-r_{1}\right)-\left(r_{2}+k_{3}\right)\left(r_{1}+k_{2}+k_{3}\right)\right]}{\left(k_{1}+k_{2}\right)\left(r_{2}-r_{1}\right)\left(r_{2}+k_{2}+k_{3}\right)} e^{r_{2} t} .
\end{aligned}
$$




$$
\begin{gathered}
\frac{S-C}{S}=\frac{\left(r_{2}+k_{3}\right)\left(r_{1}+k_{2}+k_{3}\right)+k_{1}\left(r_{2}+k_{3}\right)}{\left(k_{1}+k_{2}\right)\left(r_{2}-r_{1}\right)} e^{r_{1} t}+ \\
+\frac{\left[k_{2}\left(r_{2}-r_{1}\right)-\left(r_{2}+k_{3}\right)\left(r_{1}+k_{2}+k_{3}\right)\right]\left(r_{2}+k_{2}+k_{3}\right)+k_{1}\left[k_{2}\left(r_{2}-r_{1}\right)-\left(r_{2}+k_{3}\right)\left(r_{1}+k_{2}+k_{3}\right)\right]}{\left(k_{1}+k_{2}\right)\left(r_{2}-r_{1}\right)\left(r_{2}+k_{2}+k_{3}\right)} e^{r_{2} t}
\end{gathered}
$$

After some algebraic transformations of right part of equation (4), we can get equation (5).

Thus, we obtained equation (5), in which a quantity $\frac{S-C}{S}$ is equal to the sum of two exponents with degrees equal to $r_{1} t$ and $r_{2} t$. Consequently, this function is biexponential and it is similar to those that we have examined before [15]. It is clear that such functions in semi-logarithmic system of coordinates are represented by curves, consisting of two straightlines intersecting at a certain angle.

To get the experimental kinetic curves that are described by equation (4), at first it is necessary to find the value of $S$, that is a total amount of PRIGs in the investigated samples and is equal to the amount of PRIGs bound to immobilized antigensduring a very long time, i.e. if $t \rightarrow \infty$. For determining this value, we measured the amount of PRIGs coupled to ovalbumin during $6 \mathrm{~h}$ at $37^{\circ} \mathrm{C}$. In our experiments it was determined that the value of $S$ was approximately 20 (in units of optical density).

Then using the acquired experimental curves of dynamics of $C$ upon time, presented on Fig. 2, and the obtained value $S=20$, we have calculated the time dependence of $\frac{S-C}{S}$ on time $t$ at different temperatures. These curves are presented in the semi-logarithmic coordinates in Fig. 3. It can be seen that in this case we have got typical biexponential plots, i.e. such curves that consist of two exponents (Fig. 3). This result proves us that equation (2) describes properly the kinetics of the examined reaction PRIG-antigen binding, and, consequently, that scheme (1) and equation (3) are quite acceptable for the description of PRIGs binding to immobilized antigens.

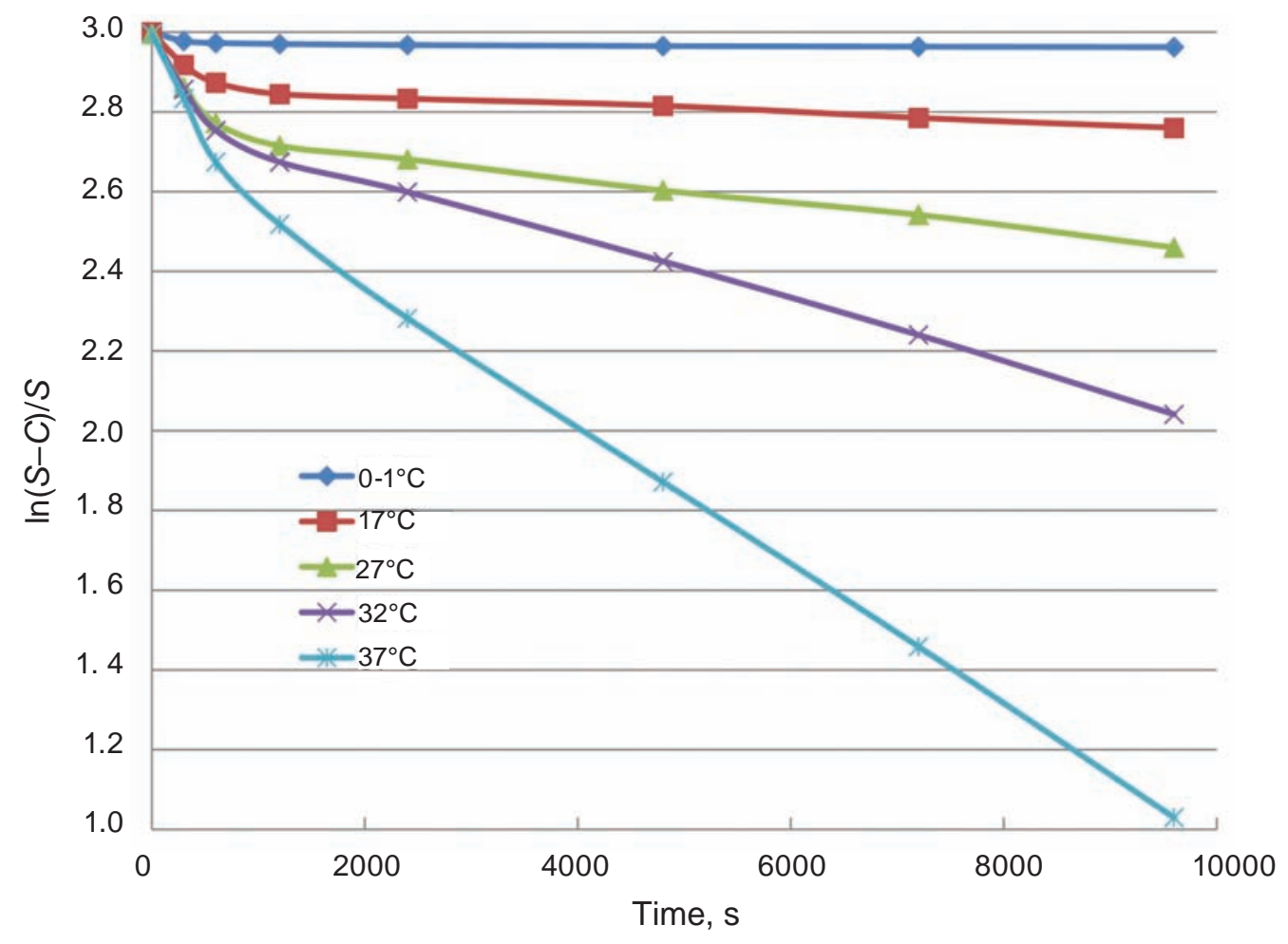

Fig. 3. Biexponential relations between values of $\ln \frac{S-C}{S}$, i.e. logarithm of the amount of PRIGs unbound to immobilized ovalbumin and incubation time $t$ 
The rate constants of PRIGs binding to immobilized ovalbuminat different temperatures

\begin{tabular}{|c|c|c|c|}
\hline $\mathrm{t}^{\circ} \mathrm{C}$ & $k_{1}, \mathrm{~s}^{-1}$ & $\mathrm{k}_{2}, \mathrm{~s}^{-1}$ & $k_{3}, \mathrm{M} \times \mathrm{s}^{-1}$ \\
\hline 0 & $8.9031 \mathrm{E}-07$ & $3.4 \mathrm{E}-05$ & $3.73 \mathrm{E}-03$ \\
\hline 17 & $1.81963 \mathrm{E}-05$ & $1.55600 \mathrm{E}-04$ & $4.87690 \mathrm{E}-03$ \\
\hline 27 & $2.99750 \mathrm{E}-05$ & $9.49800 \mathrm{E}-05$ & $2.64300 \mathrm{E}-03$ \\
\hline 32 & $8.00240 \mathrm{E}-05$ & $2.43694 \mathrm{E}-04$ & $2.71960 \mathrm{E}-03$ \\
\hline 37 & $2.04400 \mathrm{E}-04$ & $3.16340 \mathrm{E}-04$ & $1.75080 \mathrm{E}-03$ \\
\hline
\end{tabular}

Using the experimental curves of PRIGs binding to the antigen (Fig. 2), we determined (see Materials and Methods) the rate constants for this process at different temperatures (Table). The most unexpected result was that the value of rate constant $k_{3}$, that reflects the rate of "active" PRIGs binding to immobilized ovalbumin, completely does not depend on temperature. As it is obvious from the table, the values of $k_{3}$ not only do not increase with the increase of temperature, but rather tend to decline. It means that the temperature influences in a very small manner on active PRIG's binding with the immobilized antigen.

On the other hand, an incubation temperature effected significantly on the process of PRIGs activation and inactivation, as far as it influences on both values of $k_{1}$ and $k_{2}$. The value of $k_{1}$ increases with the grows of temperature especially significantly, as far as it increases from $8.90 \times 10^{-7} \mathrm{~min}^{-1}$ at $0^{\circ} \mathrm{C}$ up to $2.04 \times 10^{-4} \mathrm{~min}^{-1}$ at $37^{\circ} \mathrm{C}$, i.e. approximately in 230 times. The grows of $k_{2}$ is considerably smaller in the indicated range of temperatures, namely, from $3.40 \times 10^{-5} \mathrm{~min}^{-1}$ at $0^{\circ} \mathrm{C}$ to $3.16 \times 10^{-4} \mathrm{~min}^{-1}$ at $37^{\circ} \mathrm{C}$, i.e. approximately in 10 times.

Consequently, the most energy-dependent step in the reaction of PRIGs binding to ovalbumin is stage of transformation of "inactive" PRIGs to "active" one, i.e. induction of transitory exposure on the PRIG's surface some hydrophobic areas responsible for nonspecific binding to antigens. A reverse process, i.e. the loss of "activity" of PRIGs, requires far less energy expenses. And, finally, the binding of "active" PRIGs to hydrophobic areas of immobilized ovalbumin practically does not depend on the temperature.

Our experimental data allow us to calculate also the dependence of the ratio between concentrations of "active" and "inactive" PRIGs in solution, if the process of PRIGs binding to an antigen by one or another reason does not take place. For example, if an antigen with which an "activated" PRIG's can interact is absent, then $k_{3}$ value will be equal to zero and an equilibrium between concentrations of "active" and "inactive" PRIGs swill be established. Concentrations of "activated" and "inactivated" PRIGs in this case will be proportional to the values of $k_{1}$ and $k_{2}$, respectively.

Using the obtained values of rate constants $k_{1}$ and $k_{2}$, we will get "active"/“inactive" PRIGs ratio equal 0.026 at $0^{\circ} \mathrm{C}$. It increases to 0.117 at $17^{\circ} \mathrm{C}$ and to 0.646 at $37^{\circ} \mathrm{C}$. Thus, "active"/"inactive" PRIGs ratio under increasing the temperature from $0^{\circ} \mathrm{C}$ to $37^{\circ} \mathrm{C}$ increases from 0.026 to 0.646 , i.e. almost by 25 times.

Meantime, more importantand informative index for us is a value of part of "active" PRIGs in the pool at different temperatures. To calculate this quantity, it is necessary simply to divide the value of $k_{1}$ by the sum $k_{1}+k_{2}$. Then we can get the fact that at $0^{\circ} \mathrm{C}$ only 0.0255 of all PRIGs from those present in solution are "active". At $17^{\circ} \mathrm{C}$ this quantity is higher by four times and is equal to 0.105 . Furthermore, at $37^{\circ} \mathrm{C}$ a part of "active" PRIGs increases to 0.393 . Thus, at $37^{\circ} \mathrm{C}$ more than one third of all PRIGs (namely 0.393 of them), are in the "active" state and, consequently, is able to bind with an antigen if the PRIGs finds it. It means that reaction ability of PRIGs at $37^{\circ} \mathrm{C}$ is 15 times higher than that at $0^{\circ} \mathrm{C}$.

Because the "active" PRIGs are able to bind nonspecifically by their hydrophobic areas not only with various antigens but also with each other, it can result in self-aggregation of PRIGs. Therefore, from our calculations it becomes clear, why this process is relatively slow at $0^{\circ} \mathrm{C}$, but it gradually increases with temperature and become very high at $37^{\circ} \mathrm{C}$. If something similar can take place with solutions of some other proteins, then, presumably, the temperature dependence of the rate of its spontaneous aggregating has similar character with the aggregation of PRIGs. Thus, it can appear that the obtained dependences of rate constants of PRIGs self-aggregationon temperature can have more general character and may be inherent not only for PRIGs but also for some other proteins.

Conflict of interest. Authors have completed the Unified Conflicts of Interest form at http://ukrbiochemjournal.org/wp-content/uploads/2018/12/ coi_disclosure.pdf and declare no conflict of interest.

The work was conducted on budget costs of NAS of Ukraine, project N 0119U002511. 


\section{КІНЕТИКА ВЗАСМОДІЇ МІЖ ПОЛІРЕАКТИВНИМИ ІМУНОГЛОБУЛІНАМИ ТА АНТИГЕНОМ}

\author{
C. А. Бобровник ${ }^{1 凶}$, О. В. Оглобля, \\ М. О. Демченко ${ }^{1}$, С. В. Комісаренко
}

\author{
${ }^{1}$ Інститут біохімії ім. О. В. Палладіна \\ НАН України, Київ; \\ ${ }^{2}$ ННЦ «Інститут біології та медицини», \\ Київський національний університет \\ імені Тараса Шевченка, Україна; \\ e-mail: s-bobrov@ukr.net
}

За різних температур одержано низку кривих кінетики зв'язувания поліреактивних імуноглобулінів (ПРІГ) із іммобілізованим на імунологічних платах овальбуміном. Аналіз цих кривих дозволив зробити висновок про правильність запропонованої нами раніше моделі взаємодії ПРІГ iз антигенами, яка включає активацію ПРІГ (тобто експозицію гідрофобних участків на поверхні ПРІГ), після чого відбувається або зв'язування ПРІГ з антигеном або втрата активності молекули ПРІГ. Розроблено метод оцінки констант швидкості цього процесу 3 використанням кінетичних кривих зв'язування ПРІГ 3 антигеном. Виявлено, що зв'язування активованих молекул ПРІГ з іммобілізованим антигеном не залежить від температури. У той самий час константа швидкості процесу активації ПРІГ залежить від температури набагато більше, ніж константа швидкості процесу інактивації. Одержані значення залежності констант швидкості від температури дозволяють дійти висновку, що при $37^{\circ} \mathrm{C}$ частина активованих молекул ПРІГ у 15 разів вища, ніж при $0^{\circ} \mathrm{C}$.

К л юч о в і с ло в а: поліреактивні імуноглобуліни, антигени, кінетика взаємодії, константи швидкості.

\section{References}

1. Bobrovnik SA, Demchenko MO, Komisarenko SV. Kinetics of interaction between polyreactive immunoglobulins and antigen. The theory. Ukr Biochem J. 2019; 91(4): 88-94.

2. Bobrovnik SA. Polyreactive immunoglobulins: molecular properties and functions. Comments Mol Cell Biophys. 1999; 9: 323-356.
3. Gunti S, Herman SEM, Gottumukkala RVSRK, Xiong Y, Sun C, Carmona GN, Wiestner A, Notkins AL. Polyreactive antibodies in CLL correlate with the level of immunoglobulins not the number of B lymphocytes. Leuk Lymphoma. 2019; 60(1): 242-245.

4. Liao H, Zhang Z. Polyreactive Antibodies in Anti-HIV-1 Responses. Curr Mol Med. 2018; 18(2): 126-133.

5. Ravindranath MH. HLA Class Ia and Ib Polyreactive Anti-HLA-E IgG2a Monoclonal Antibodies (TFL-006 and TFL-007) Suppress Anti-HLA IgG Production by CD19+ B Cells and Proliferation of CD4+ $\mathrm{T}$ Cells While Upregulating Tregs. J Immunol Res. 2017; 2017: 3475926.

6. Bunker JJ, Erickson SA, Flynn TM, Henry C, Koval JC, Meisel M, Jabri B, Antonopoulos DA, Wilson PC, Bendelac A. Natural polyreactive $\operatorname{IgA}$ antibodies coat the intestinal microbiota. Science. 2017; 358(6361): eaan6619.

7. Liao H, Yu Y, Li S, Yue Y, Tao C, Su K, Zhang Z. Circulating plasmablasts from chronically human immunodeficiency virus-infected individuals predominantly produce polyreactive/ autoreactive antibodies. Front Immunol. 2017; 8: 1691.

8. Zorn E, See SB. Polyreactive natural antibodies in transplantation. Curr Opin Organ Transplant. 2017; 22(1): 8-13.

9. Lecerf M, Jarossay A, Kaveri SV, LacroixDesmazes S, Dimitrov JD. Methods for posttranslational induction of polyreactivity of antibodies. Methods Mol Biol. 2017; 1643: 135145.

10. Gunti S, Notkins AL. Polyreactive antibodies: function and quantification. J Infect Dis. 2015; 212(Suppl 1): S42-S46.

11. Dimitrov JD, Planchais C, Roumenina LT, Vassilev TL, Kaveri SV, Lacroix-Desmazes S. Antibody polyreactivity in health and disease: statu variabilis. J Immunol. 2013; 191(3): 993999.

12. Mahendra A, Gangadharan B, André S, Boudjoghra M, Davi F, Lecerf M, Planchais C, Kaveri SV, Lacroix-Desmazes S, Dimitrov JD. Cryptic polyreactivity of IgG expressed by splenic marginal zone B-cell lymphoma. Mol Immunol. 2014; 60(1): 54-61. 
13. Bobrovnik SA. Polyreactive immunoglobulins recognize hydrophobic parts of proteins. Ukr Biokhim Zhurn. 2001; 73(2): 116-122. (In Russian).
14. Bobrovnik SA, Marinets AV. Properties of polyreactive immunoglobulins. Ukr Biokhim Zhurn. 1993; 65(5): 21-26. (In Russian).

15. Bobrovnik SA. Determination the rate constants of some biexponential reactions. $J$ Biochem Biophys Methods. 2000; 42(1-2): 49-63. 